\title{
24. JURASSIC OSTRACODES OF DEEP SEA DRILLING PROJECT LEG 76, HOLE 534A, BLAKE-BAHAMA BASIN 1
}

\author{
Henri J. Oertli, Elf Aquitaine, Centre Micoulau, Pau, France
}

\begin{abstract}
The ostracode assemblage found in Upper Jurassic cores of Hole 534A, Leg 76 of the Deep Sea Drilling Project (DSDP), bears some resemblance to that of Sites 100 and 105, DSDP Leg 11, all in the Blake-Bahama Basin. The Hole 534A assemblage, containing 14 species represented by one or more specimens only, is much less diversified than that of Sites 100 and 105. Both are deemed typical of a deep-sea environment. Even if the Late Jurassic assignment is not in doubt, precise dating using the ostracodes is impossible. Kimmeridgian strata may extend as deep as Core 110.
\end{abstract}

\section{INTRODUCTION}

I was delighted when Felix Gradstein invited me to study the Jurassic ostracodes of Leg 76. The aim of this leg was similar to that of Leg 11 (in which Sites 100 and 105 had yielded quite diversified ostracode assemblages; Oertli, 1972); it was hoped that the same species would be found on Leg 76. Sites 390 and 392 of Leg 44 are situated in the same region, but no Jurassic sediments were obtained (V. Swain, 1978, who studied the Cretaceous ostracodes of these sites) (Fig. 1). However, a study of nearly 100 core samples of Hole 534A (between Cores 51 and 112) put an end to this hope: little more than $10 \%$ yielded ostracodes, and half of these were undeterminable, being mostly fragments. Fortunately, Dr. Gradstein later provided me with a collection containing some more material from 19 cores, between 93 and 126 , corresponding to the Jurassic sequence of this hole.

The few fossiliferous Cretaceous samples yielded only Cytherella sp. and Asciocythere brevis Cornuel (in Samples $534 \mathrm{~A}-58-2,2 \mathrm{~cm}$ and $534 \mathrm{~A}-60-1,58 \mathrm{~cm}$ ) among the determinable forms. This explains why the present study is limited to the scarce Jurassic material.

\section{FAUNAL RECORD}

As can be seen in Figure 2, the total number of distinguishable species is very modest; the "?"' is a common sign. Adult or at least "normal-sized"' individuals are rare (see magnification scale on the plates), and the "richest column" is that marked "Indet." (indeterminate); nevertheless, a few interesting findings are listed.

\section{Bairdia "striate" (Plate 1, Figs. 1-4)}

A peculiar form, with its concentric striae, sometimes combined with reticulation, most developed along the anterior, dorsal, and posterior margins. It is the most widely distributed species, having been found in 10 or 11 of 25 samples. The same species has been observed in Leg 11, Site 105, Cores 33 and 38.

\footnotetext{
${ }^{1}$ Sheridan, R. E., Gradstein, F. M., et al., Init. Repts. DSDP, 76: Washington (U.S. Govt. Printing Office).
}

Procytheropteron aff. prolongatum (Sharapova, 1939) (Plate 1, Figs. 6-9)

The second most frequent species, it was found in 6 samples, between Cores 94 and 102 . It strongly resembles $P$. prolongatum (upper Kimmeridgian to middle Volgian), Volga region and Ukraine (see Fuller, 1980), but is less elongate and has a more concentric reticulation. Its size (adults, $0.27-0.32 \mathrm{~mm}$ ) is little more than half that of the Russian species.

\section{Bairdia umbra Oertli, 1967 (Plate 1, Fig. 5)}

A single valve was found in a sample of which the exact depth is undetermined, but which is situated below Core 115 . The species was originally described from the bathyal Upper Jurassic of the Apennines, and a related species (B. italica Oertli, 1967) could be determined in Leg 11, Site 105. After comparison with type material, the specific identification appears "reasonable." This specimen is, however, smaller $-0.92 \mathrm{~mm}$.

\section{Paranotacythere? sp. (Plate 2, Fig. 1)}

One right valve was found in Core 115. The same species was observed in Core 9 of Site 100, Leg 11 (length $=0.38 \mathrm{~mm}$.)

\section{Indeterminate Genera and Species}

1) One form is apparently the same as that found on Leg 11 at Site 100, Core 7 (Oertli, 1972, plate 4, fig. 50). It is located in our material in Core 110; see Plate 2, Figure 5 (length $=0.29 \mathrm{~mm}$ ). Other specimens also resemble forms encountered in Leg 11 material, but probably without being co-specific. These are:

2) Indet. gen. et sp. aff. Oertli, 1972, (plate 4, figure 71). This elongate, flat form (a single specimen from Core 110, Plate 2, Fig. 4) with large caudal processus toward the anterior has some similarity with the species shown in 1972; but those are more blunt, the posterior is turned upward, and the costulation is more pronounced (length $=0.38 \mathrm{~mm}$ ).

3) Indet. gen. et sp. (Argilloecia? sp.). This is an incomplete specimen of approximately $0.38 \mathrm{~mm}$, vaguely 


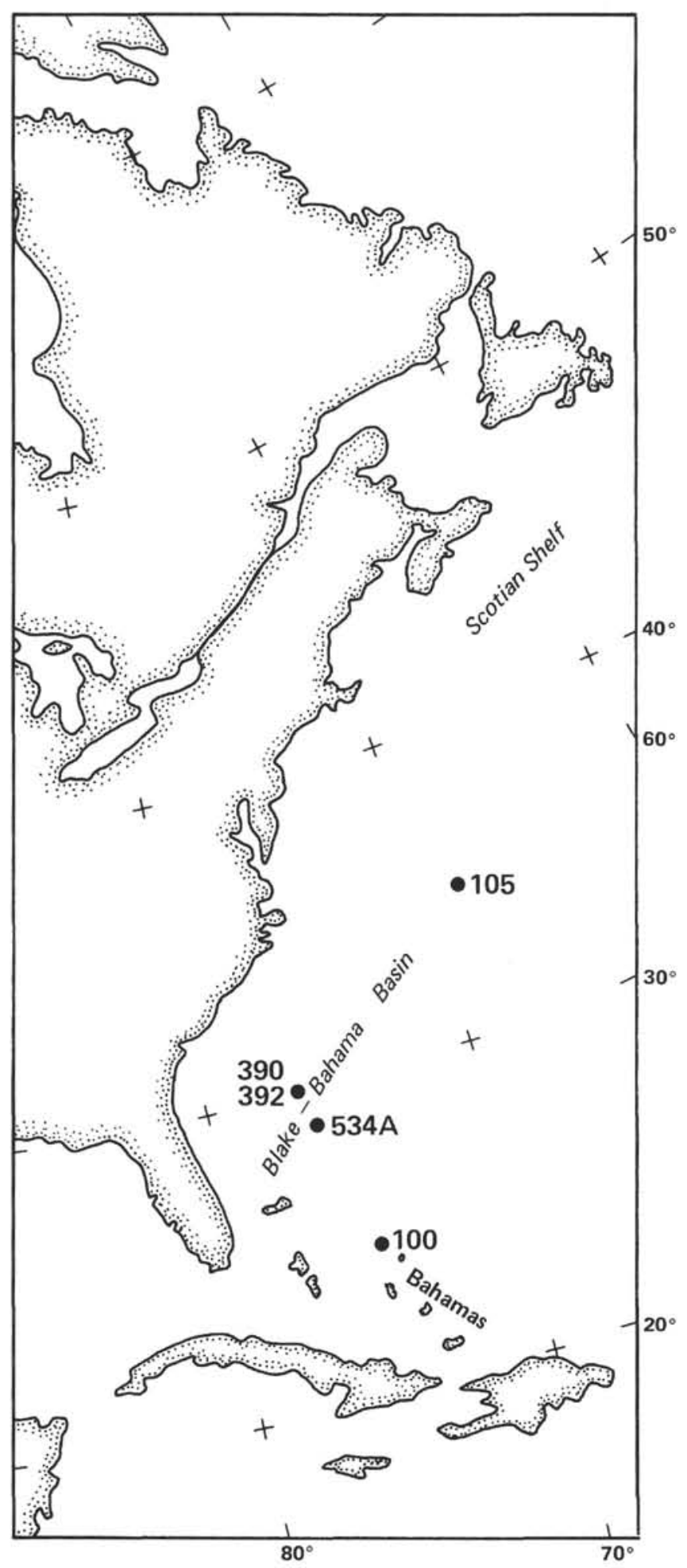

Figure 1. Location map of the sites discussed.

related to what was called in Oertli, 1972, Fabalicypris sp. (found in Core 115, Plate 2, Fig. 2).

4) Indet. gen. et sp. (aff. Pseudoperissocytheridea parahieroglyphica Whatley, 1970). Of this form too, a single but badly preserved specimen was found in Core 115 (Plate 2, Fig. 3). It is not dissimilar to the cited spe- cies from the Scottish Oxfordian, though the latter is approximately twice its size (length of our specimen = $0.31 \mathrm{~mm}$ ).

Other problematical identifications at the genus level include:

1) Pontocyprella? sp. from Core 93 (the determination is not sure because the posteroventral margin may be incomplete). (Length $=0.41 \mathrm{~mm}$; Plate 2, Fig. 7.)

2) Macrocypris? sp. or Paracypris? sp. (Core 94). A left valve, broken posteriorly. (Length $=$ more than 0.39 mm. Plate 2, Fig. 8.)

3) Bythocypris? sp. A single carapace from Core 97 (Plate 2, Fig. 9)-one of the rare specimens of normal size $(0.71 \mathrm{~mm})$. Our specimen bears a slight resemblance to Bythocypris ambitruncata Peterson, 1954 (Rierdon Formation, Montana).

4) Trachycythere? sp. Vesticytherura? sp. Found in Core 104 (Plate 2, Fig. 6), this form is most probably an internal mold and therefore of little interest. (Length $=$ $0.48 \mathrm{~mm}$.)

5) Patellacythere? sp. Found in Core 104, this is a very badly preserved specimen for which the given determination is most uncertain. (Length $=0.38 \mathrm{~mm}$; Plate 2, Fig. 10.)

Finally, in Plate 2, Figures 11 and 12, two specimens of very limited size are shown that do not deserve special comment, but may possibly be familiar to colleagues.

\section{DATING-CORRELATION AND PALEOECOLOGY}

The lack of similarity to western European Callovian and Upper Jurassic ostracode assemblages prevents precise dating of the Leg 76 association. Of the species already observed in Leg 11, Bairdia "striate" is not stratigraphically interesting, obviously having a long range. Better information (though to be used with caution, because it is based on single specimens of rare species) includes:

For core 110: Indet. gen. et sp. (figured on plate 4, fig. 50, in Oertli, 1972); its occurrence (in DSDP Section $100-7-2$ ) is attributed to the Tithonian to Kimmeridgian (?) by Luterbacher (1972).

For core 115: Paranotacythere? sp. (figured as Orthonotacythere sp. on plate 4, figs. 56-57, in Oertli, 1972 , and found in DSDP Sample 100-9,CC); Luterbacher (1972) attributes this sample to the Kimmeridgian(?) to Oxfordian(?).

Bairdia umbra Oertli, 1967 was found in the Apennines in Upper Jurassic deposits, but below the Tithonian.

There is a close resemblance to Upper Jurassic ostracode assemblages from the Scotian Shelf (Ascoli, 1976, 1981; Jansa et al., 1980). According to P. Ascoli (personal communication, May 25 and September, 1981), Oxfordian ostracode assemblages are very scarce on the Scotian Shelf, except in a conventional bottom core, where he tentatively identifed over 30 species. Among these, three species described in 1972 by this author in the Jurassic sediments of DSDP Leg 11 (Acrocythere? sp., Bairdia italica Oertli and Indet. gen. et sp. of plate 4 , fig. 58) seem to be present. 


\begin{tabular}{|c|c|c|c|c|c|c|c|c|c|c|c|c|c|c|c|c|c|c|c|c|c|c|c|c|c|c|c|c|}
\hline \multirow{2}{*}{\multicolumn{2}{|c|}{$\begin{array}{c}\text { Appearing } \\
\text { in }\end{array}$}} & \multirow{3}{*}{ 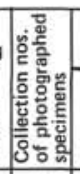 } & \\
\hline & & & \multicolumn{26}{|c|}{\begin{tabular}{l|l|l|l|l|l|} 
Jurassic ostracodes or Leg /6, Hole & (34A \\
96 & 97 & 99 & 100 & 101
\end{tabular}} \\
\hline$\frac{\frac{m}{a}}{a}$ & 善 & & Species & $\begin{array}{c}2 \\
45-46\end{array}$ & $\underset{6 \rightarrow 7}{3}$ & $\begin{array}{c}1 \\
140-142\end{array}$ & $\underset{47-48}{4}$ & cc & $1_{88-89}^{1}$ & $\underset{6-8}{3}$ & $\begin{array}{c}97 \\
1 \\
8-9 \\
\end{array}$ & $\begin{array}{c}1 \\
4-6\end{array}$ & $\begin{array}{c}1 \\
38-40\end{array}$ & \begin{tabular}{|c|}
3 \\
$n-78$ \\
\end{tabular} & \begin{tabular}{|c|}
4 \\
$46-47$ \\
\end{tabular} & \begin{tabular}{|c|}
101 \\
2 \\
$140-142$ \\
\end{tabular} & $\begin{array}{c}5 \\
75-77\end{array}$ & \begin{tabular}{|c|c|}
1 \\
$60-62$
\end{tabular} & $\begin{array}{c}4 \\
33-34\end{array}$ & \begin{tabular}{|c|}
1 \\
$52-53$ \\
\end{tabular} & $\begin{array}{c}2 \\
100-102\end{array}$ & $\begin{array}{c}1 \\
1 \\
45-47\end{array}$ & $\mathrm{cc}$ & $\begin{array}{c}1 \\
7-8\end{array}$ & $\underset{6-8}{1}$ & $\begin{array}{c}120 \\
3 \\
120-122\end{array}$ & A & B \\
\hline 2 & 7 & ${ }_{3}^{\prime \prime I}$ & Pontocyprella? sp. linstar) & & & & & & & & & & & & & & & & & & & & & & & & & \\
\hline 2 & $11-12$ & & $\begin{array}{l}\text { Indet. (fragments, deformed and/or badly } \\
\text { preserved specimens, molds) }\end{array}$ & & & & & & & & & & & & & & & & & & & & & & & & & \\
\hline 1 & $1-4$ & $\begin{array}{c}\text { IV } \\
6.5 \\
2,5,10\end{array}$ & \begin{tabular}{|ccc} 
Bairda & striate & $\begin{array}{l}\text { (mostly instars and fragments) } \\
\mid=\text { Bairda? sp. in Leg 11) }\end{array}$ \\
\end{tabular} & & & & & & & 2010 & & & & & & & & $-\infty-$ & & & & & & & & & & \\
\hline 2 & 8 & $\begin{array}{l}\mathrm{v} \\
3\end{array}$ & Macrocypris? sp. or Paracypris? sp. (instar) & & & & & & & & & & & & & & & & & & & & & & & & & \\
\hline 1 & $6-9$ & $\begin{array}{l}1,1 / 7 \\
4,57 \\
4,6,7\end{array}$ & \begin{tabular}{|l|}
$\begin{array}{l}\text { Procytheropteron aff. prolongatum } \\
\text { (Sharapova, 1939) }\end{array}$ \\
\end{tabular} & & & & & & & & & & & & & & & & & & & & & & & & & \\
\hline 2 & 9 & $\begin{array}{c}\text { iv } \\
2\end{array}$ & Bythocypris? sp. & & & & & & & & & & & & & & & & & & & & & & & & & \\
\hline 2 & 6 & "'1' & Trachycythere? or Vesticytherura? sp. (mold) & & & & & & & & & & & & & & & & & & & & & & & & & \\
\hline 2 & 10 & $\begin{array}{l}\text { IV } \\
8\end{array}$ & Patellacythere? sp. & & & & & & & & & & & & & & & & & & & & & & & & & \\
\hline 2 & 4 & $\begin{array}{l}V \\
g\end{array}$ & $\begin{array}{l}\text { Indet. gen. et sp. aff. } \\
\text { Oertli, } 1972 \text { (pl. 4, fig. 71) }\end{array}$ & & & & & & & & & & & & & & & & & & & & & & & & & \\
\hline 2 & 5 & $v$ & $\begin{array}{l}\text { Indet. gen. et sp. of Oertti, } 1972 \\
\text { (pl. 4, fig. 50) }\end{array}$ & & & & & & & & & & & & & & & & & & & & & & & & & \\
\hline 2 & 1 & $\begin{array}{ll}\text { vi } \\
4\end{array}$ & $\begin{array}{l}\text { Paranotacythere? sp. } \\
\text { Orthonotacythere sp. of Oertli, } 1972 \text { (pl. 4, figs, 56-57) }\end{array}$ & & & & & & & & & & & & & & & & & & & & & & & & & \\
\hline 2 & 2 & $\begin{array}{ll}v_{1} \\
1\end{array}$ & $\begin{array}{l}\text { Indet, gen. et sp. (Argilloecia? sp.; cf. } \\
\text { Fabalicypris? sp. of Oertli, } 1972 \text { [pl. 1, fig. 17]) }\end{array}$ & & & & & & & & & & & & & & & & & & & & & & & & & \\
\hline 2 & 3 & $\begin{array}{ll}\text { vi } \\
2\end{array}$ & $\begin{array}{l}\text { Indet. gen. et sp. (aff. Pseudoperissocytheridea } \\
\text { parahierog'lyphica Whatley, 1970) }\end{array}$ & & & & & & & & & & & & & & & & & & & & & & & & & \\
\hline 1 & 5 & $\begin{array}{ll}\mathrm{VI} \\
5\end{array}$ & Bairda umbra Oertli, 1967 & & & & & & & & & & & & & & & & & & & & & & & & & \\
\hline
\end{tabular}

Figure 2. Distribution of ostracodes. (글 means: SEM stub, third row, third specimen from the left, and so on.) 
Ostracodes from the Kimmeridgian and younger Jurassic strata of the Scotian Shelf resemble European Shelf assemblages of that time, which contrast with the associations of Legs 11 and 76.

The specific composition of the Leg 11 and Leg 76 associations and their scarcity make it probable that the depositional environment was situated beyond the continental shelf. The reduced size may be interpreted as a sign of precarious nutritional conditions.

\section{ACKNOWLEDGMENTS}

My sincerest thanks go to Piero Ascoli, Richard Benson, and John Neale for their critical reading of the paper and helpful comments. The management of Elf Aquitaine provided facilities for working on the material and granted permission for publication.

\section{REFERENCES}

Ascoli, P., 1976. Foraminiferal and ostracod biostratigraphy of the Mesozoic-Cenozoic, Scotian Shelf, Atlantic Canada. Marit. Sediments, Spec. Publ., 1:653-771.
1981. Foraminiferal-ostracod Late Jurassic biozonation of the Scotian Shelf. Geol. Surv. Ottawa, Open File 753.

Fuller, N., 1980. On Procytheropteron prolongatum (Sharapova). A Stereo-Atlas of Ostracod Shells, 7:117-224.

Jansa, L. F., Remane, J., and Ascoli, P., 1980. Calpionellid and foraminiferal ostracod biostratigraphy at the Jurassic-Cretaceous boundary, offshore eastern Canada. Riv. Ital. Paleontol., 86: 67-126.

Luterbacher, H., 1972. Foraminifera from the Lower Cretaceous and Upper Jurassic of the northwestern Atlantic. In Hollister, C. D., Ewing, J. I., et al., Init. Repts. DSDP, 11: Washington (U.S. Govt. Printing Office), 561-593.

Oertli, H. J., 1972. Jurassic ostracodes of DSDP Leg 11 (Sites 100 and 105) - preliminary account. In Hollister, C. D., Ewing, J. I., et al., Init. Repts. DSDP, 11: Washington (U.S. Govt. Printing Office), 645-657.

Swain, F. M., 1978. Notes on Cretaceous ostracoda from DSDP Leg 44, Sites 390 and 392 . In Benson, W. E., Sheridan, R. E., et al., Init. Repts. DSDP, 44: Washington (U.S. Govt. Printing Office), 921-937.

Date of Initial Receipt: February 23, 1982 

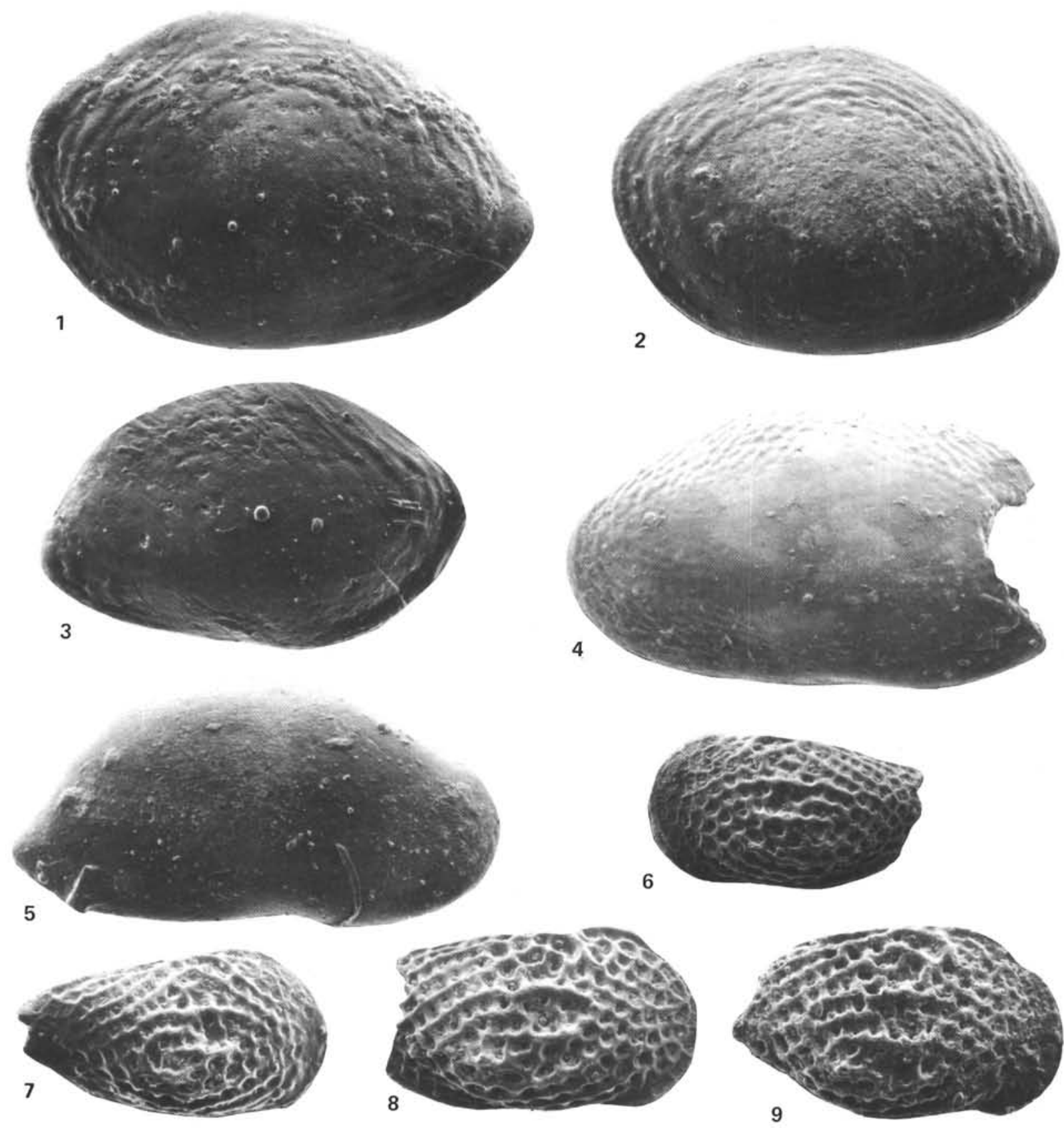

Plate 1. Jurassic ostracodes. (All specimens with the exception of Figs. 4 and 5 are magnified approximately $\times 160$; Figs. 4 and 5 are magnified $\times 80$. All specimens are single valves.) 1-4. Bairdia "striate," (1) Sample 534A-110,CC. (2) Sample 534A-94-1, 140-142 cm. (3) Sample 534A96-3, 6-8 cm. (4) Sample 534A-101-2, 140-142 cm. 5. Bairdia umbra Oertli, 1967. Sample 534A, below core 115. 6-9. Procytheropteron aff. prolongatum (Sharapova, 1939). 6. Sample 534A-99-3, 77-78 cm. 7. Sample 534A-99-1, 4-6 cm. 8. Sample 534A-101-2, $140-142 \mathrm{~cm} . \quad 9$. Sample 534A-94,CC. 

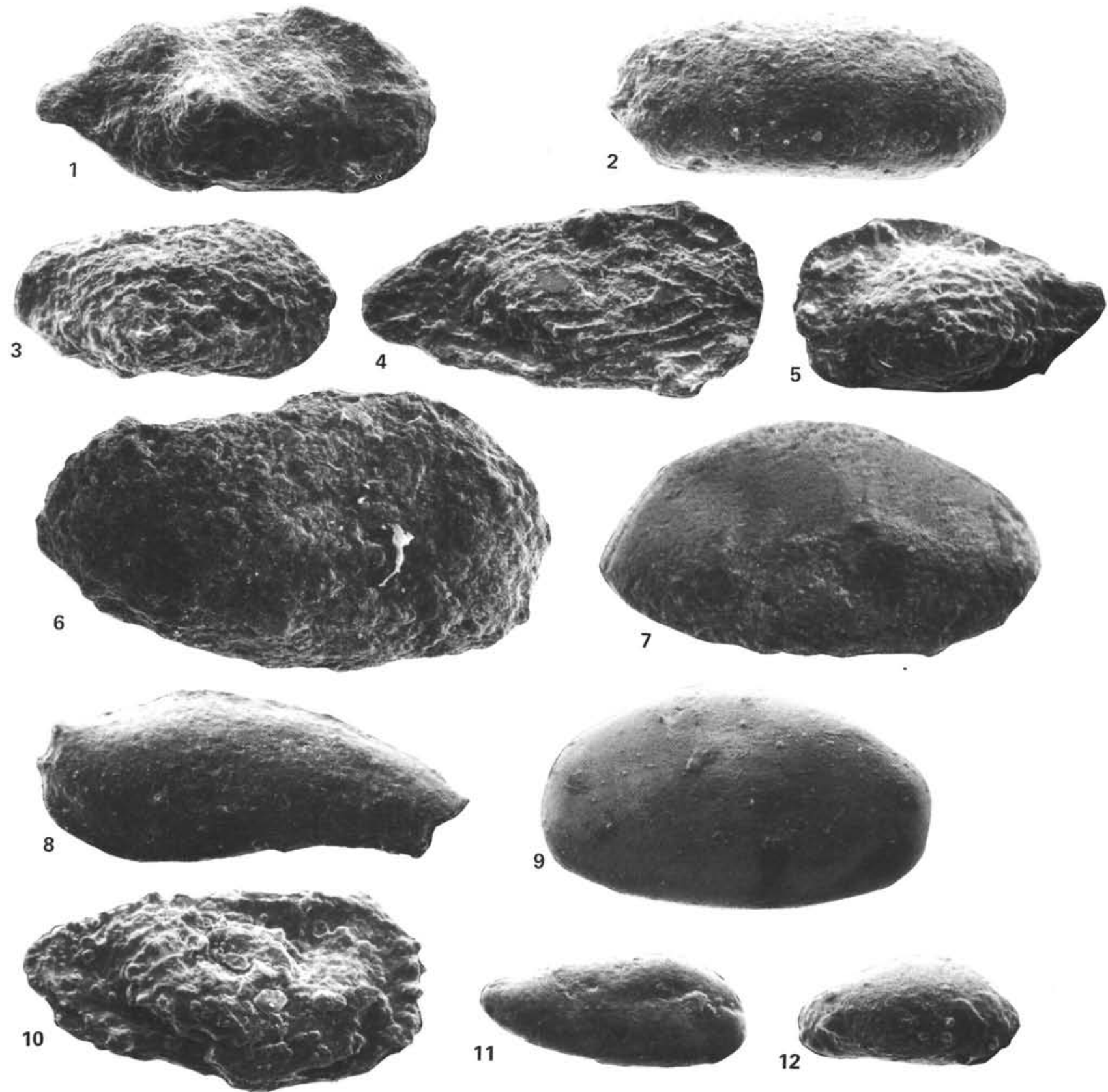

Plate 2. Jurassic ostracodes. (All specimens with the exception of Fig. 9 are magnified approximately $\times 160$; Fig. 9 is magnified $\times 80$. Figs. 1, 2, 3, $8,9,11$, and 12 represent single valves, the others are carapaces.) 1. Paranotacythere? sp. Sample 534A-115-1, 6-8 cm. 2. Indet. gen. et sp.: Argilloecia? sp. Sample 534A-115-1, 6-8 cm. 3. Indet. gen. et sp.: aff. Pseudoperissocytheridea parahieroglyphica Whatley, 1970. Sample 534A-115-1, 6-8 cm. 4. Indet. gen. et sp.: aff. Oertli, 1972, pl. 4, fig. 71. Sample 534A-110,CC. 5. Indet. gen. et sp.: Oertli, 1972, pl. 4, fig. 50. Sample 534A-110,CC. 6. Trachycythere? sp., Vesticytherura? sp. (probably mold). Sample 534A-104-1, 60-62 cm. 7. Pontocyprella? sp. Sample 534A-93-2, 45-46 cm. 8. Macrocypris? sp. or Paracypris? sp. Sample 534A-94-1, 140-142 cm. 9. Bythocypris? sp. Sample 534A-971, 8-9 cm. 10. Patellacythere? sp. Sample 534A-104-4, 33-34 cm. 11. Indet. Sample 534A-126-3, 120-122 cm. 12. Indet. Sample 534A-115$1,6-8 \mathrm{~cm}$. 